\title{
The Collision of Unbelted Passenger with Assessment of Various Vehicle Interior
}

Stanislav Špirk

Regional Technological Institute, Faculty of Mechanical Engineering, University of West Bohemia, Univerzitni 8, 306 14 Pilsen, Czech Republic, E-mail: spirks@rti.zcu.cz

This paper describes the conception of vehicle interior which can help decrease the injury risk of unbelted passenger. This paper is primarily aimed to the field of rail vehicles, but the results are useful for more transportation industries. Some computer simulations for passive safety performance assessment were conducted in previous years. The FE models of the interiors based on data from actually operated vehicles were prepared for this purpose. The newly prepared simulations are close to the real interior models. Combinations of rigid walls were used for modelling. Each model contains a short python code which allows change of interior disposition. This approach is close to an optimisation process. The main goal is to compare all possible configurations of interior. In practise it is usually obvious which change can improve the passive safety, but with numerical approach is possible to find structures with unknown influences. The simulations were performed in software environment PAM-CRASH. It is used a dummy Multibody model of the human body ARB Hybrid III 50th percentile.

Keywords: Passive safety, interior, crash, crashworthiness, biomechanics

\section{Acknowledgement}

The present contribution was prepared by financial support of the project LO1502 'Development of the Regional Technological Institute' carried out under the auspices of the National Sustainability Programme I of the Ministry of Education of the Czech Republic aimed to support research, experimental development and innovation.

\section{References}

[1] Railroad Group Standard GM/RT2100 Issue 5. June 2012

[2] REIS, P. N. B., FERREIRA, J. A. M., \& RODRIGUES, N. F. S. (2011). Impact behaviour of panels for automotive applications. Strain, 47(SUPPL. 2), 79-86. doi:10.1111/j.1475-1305.2010.00735.x

[3] AVALLE, M., BELINGARDI, G., \& MONTANINI, R. (2001). Characterization of polymeric structural foams under compressive impact loading by means of energy-absorption diagram. International Journal of Impact Engineering, 25(5), 455-472. doi:10.1016/S0734-743X(00)00060-9

[4] HORSCH, J. D., MELVIN, J. W., VIANO, D. C., \& MERTZ, H. J. (1991). Thoracic injury assessment of belt restraint systems based on hybrid III chest compression. Paper presented at the Proceedings - Society of Automotive Engineers, (P-251) 85-108.

[5] HYNCIK, L., MANAS, J., SPICKA, J., SPIRK, S., \& KOVAR, L. (2014). Development of 6 years old child virtual model by automatic scaling. SAE Technical Papers, 2 doi:10.4271/2014-01-2028

[6] D. CHICOS, D. VOGEL, M. OTTO, O. SCHAAR, a kol., "Crash Analysis Criteria Description.", Bundesanstalt, October 2006.

[7] DIGGES, H. (1998). Injury Measurements and Criteria, The National Crash Analysis Center, The George Washington University, 1998

[8] KEPKA, M., CHVOJAN, J., SPIRK, S., HELLER, P., BARTON, L., \& KEPKA, M., JR. (2016). Laboratory fatigue tests in the design and development of new vehicles. Civil-Comp Proceedings, 110

[9] MARIANA PAULINO AND FILIPE TEIXEIRA-DIAS (2012). On the Use of Polyurethane Foam Paddings to Improve Passive Safety in Crashworthiness Applications, Polyurethane, Dr. Fahmina Zafar (Ed.), ISBN: 978-95351-0726-2, InTech, DOI: 10.5772/47996. Available from: http://www.intechopen.com/books/polyurethane/onthe-use-of-polyurethane-foam-paddings-to-improve-passive-safety-in-crashworthiness-applications

[10] EN 15227:2008, "Railway applications - Crashworthiness requirements for railway vehicle bodies.", July 2008

[11] MADLOVA,D., GEBHAR, V. (2016). Occupational Health and Safety Hazards in Machining, Manufacturing Technology, pages 740-743, No. of article M2016138

[12] CHVAL, Z., SEDLACEK, F., KEMKA, V. (2017). Usage of FEM Simulations in Design of Piping Systems, Manufacturing Technology, Vol. 17., No. 4, pp. 469-473.

[13] RAZ, K., HORA, J., PAVLATA, P. (2017) Unconventional Materials Usage in Design of Vehicle Bodies, Manufacturing Technology, Vol. 17., No. 5, pp. 823-827. 